Maciej Zdanek

Archiwum Uniwersytetu Jagiellońskiego

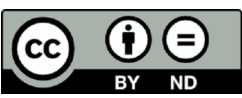

\title{
Dzieło naukowe i bibliografia prac Leszka Hajdukiewicza
}

\author{
Pamięci Profesora Leszka Hajdukiewicza \\ $w$ dwudziesta rocznice śmierci
}

Leszek Hajdukiewicz (24 I 1924-11 IX 1995), profesor Uniwersytetu Jagiellońskiego i długoletni kierownik Archiwum UJ (1963-1994), był wybitnym historykiem kultury epoki staropolskiej, zwłaszcza wieków XVI-XVII ${ }^{1}$. W dotychczasowych omówieniach jego dorobku naukowego wskazano już podstawowe kierunki jego badań: dzieje szkolnictwa, zwłaszcza Uniwersytetu Jagiellońskiego, historię nauki, książki i bibliotek, a także biografistykę profesury krakowskiej oraz ludzi kultury epoki renesansu i baroku. Ta bogata twórczość nie doczekała

${ }^{1}$ Podstawowe informacje biograficzne przekazano we wspomnieniach pośmiertnych. Zob. [anonimowo] Leszek Hajdukiewicz (1924-1995), „Acta Universitatis Iagellonicae”, XIII, 1995, 1 (194), s. 20; W. Bieńkowski, Leszek Hajdukiewicz (1924-1995), „Odrodzenie i Reformacja w Polsce”, XL, 1996, s. 166-169; J. Dybiec, Leszek Hajdukiewicz (24 I 1924-11 IX 1995), „Kwartalnik Historyczny”, CIII, 1996, 2, s. 131-133; idem, Leszek Hajdukiewicz (1924-1995), „Kwartalnik Historii Nauki i Techniki”, XLI, 1996, 2, s. 141-144; U. Perkowska, Leszek Hajdukiewicz (24 I 1924-11 IX 1995), „Archeion”, XCVIII, 1997, s. 346-348. Najpełniejszy biogram i omówienie twórczości dał A. K. Banach, Leszek Hajdukiewicz (1924-1995), [w:] Uniwersytet Jagielloński. Ztota ksiegga Wydziatu Historycznego, red. J. Dybiec, Kraków 2000, s. 525-532. Zob. też J. Dybiec, Leszek Hajdukiewicz (1924-1995), [w:] Historia wychowania w XX wieku. Dorobek i perspektywy, red. T. Gumuła, J. Krasuski, S. Majewski, Kielce 1998, s. 141-143; K. Zwiercan, Hajdukiewicz Leszek (1924-1995), [w:] Stownik biograficzny polskiej historii wychowania, red. A. Meissner, W. Szulakiewicz, Toruń 2008, s. 276-283; J. Sondel, Stownik historii i tradycji Uniwersytetu Jagiellońskiego, Kraków 2012, s. 480-481. 
się jednak bibliograficznego zestawienia prac drukowanych, które pozwalałoby unaocznić wielość i różnorodność nie tylko podejmowanych przezeń zagadnień badawczych, ale też organizacyjnych. Wiele nowych danych do portretu naukowego Hajdukiewicza wnosi też zachowana w Archiwum UJ spuścizna naukowa, pokazując pełniej ścieżki rozwoju uczonego, a także twórcze niespełnienia i bezdroża ${ }^{2}$.

W biografii naukowej i twórczości L. Hajdukiewicza dają się wyodrębnić trzy fazy. Pierwsza obejmuje czas od debiutu naukowego do roku 1963. Karierę naukową rozpoczynał po studiach na Wydziale Humanistycznym UJ, gdzie w 1950 r. uzyskał stopień magistra filozofii. Uczęszczał na seminaria Władysława Semkowicza i Henryka Barycza, przyszłego promotora i mistrza. Pod jego kierunkiem powstała wybitna rozprawa o szkole zamkowej krakowskiej ${ }^{3}$. Z inspiracji Barycza płynęło wiele: sposób postrzegania rzeczywistości dziejowej, erudycyjność ujęcia, specyficzny styl języka naukowego i nade wszystko zainteresowanie dziejami oświaty i kultury umysłowej. Drugim miejscem, które intelektualnie ukształtowało Hajdukiewicza, był Oddział Rękopisów Biblioteki Jagiellońskiej, gdzie pracował w latach 1950-1956 pod kierunkiem Władysława Pociechy ${ }^{4}$. Osobowość i badania Pociechy, praca nad inwentaryzacją rękopisów ${ }^{5}$, zetknięcie się ze światem inkunabułów i starodruków, nabycie umiejętności warsztatowych kodykologa i bibliologa otworzyło przed Hajdukiewiczem nowe przestrzenie badawcze: księgozbiory mecenasów i uczonych polskiego renesansu w szerokim kontekście ich biografii, związków z Europą i myślą epoki.

Trzecim miejscem formacji warsztatowej była Polska Akademia Nauk, w 1951 r. rozpoczął bowiem współpracę z Redakcją Bibliografii

${ }^{2}$ Kraków, Archiwum UJ (dalej: AUJ), sygn. Sp. 168 (dawniej D-CLXVI).

3 Por. W. Szulakiewicz, Historia oświaty i wychowania w Polsce 1944-1956, Kraków 2006, s. 211.

${ }^{4}$ Z. Ciechowska, Wtadystaw Pociecha w Bibliotece Jagiellońskiej, „Biuletyn Biblioteki Jagiellońskiej”, X, 1958, 1, s. 5-10; J. Zathey, Ze wspomnień o wspótpracy z Wtadystawem Pociecha, „Biuletyn Biblioteki Jagiellońskiej”, X, 1958, 1, s. 10-12 (tu wspomniany L. Hajdukiewicz).

5 Hajdukiewicz opracował wtedy wstępne opisy katalogowe rękopisów BJ, sygn. 6201-6236, 6238-6320. Zob. J. Zathey, Przedmowa, [w:] Inwentarz rękopisów Biblioteki Jagiellońskiej nr 6001-7000, cz. 1, nr 6001-6500, oprac. A. Jałbrzykowska, J. Zathey przy współudziale Z. Łagodowej, J. Tyszkowskiej, Kraków 1962, s. X-XI. Ponadto opracowywał archiwum Wacława Aleksandra Maciejowskiego i Władysława Orkana. Zob. J. Zathey, Przedmowa, [w:] Inwentarz rękopisów Biblioteki Jagiellońskiej nr 8001-9000, cz. 1, nr 8001-8500, oprac. W. Bandura, A. Jałbrzykowska, Kraków 1971, s. 9. 
Historii Polski przy Zarządzie Głównym PTH, a od 1953 r. - z Zakładem Dokumentacji IH PAN, który przejął jej agendy. Wtedy właśnie utrwaliły się takie cechy jego profilu twórczego jak zamiłowanie do bibliografii, inwentaryzacji źródłowej i pracy dokumentacyjnej. Umocniła to podjęta w 1956 r. praca w Zakładzie Historii Nauki i Techniki PAN, w tzw. Zespole Odrodzenia pod kierunkiem H. Barycza, gdzie Hajdukiewicz pracował do 1961 r. Równolegle od 1958 r. był adiunktem przy Katedrze Historii Nauki i Oświaty UJ. Taki przebieg kariery zawodowej sprawił, że odszedł od pierwotnego tematu doktoratu - Uniwersytet Jagielloński w latach 1794-1809. Intensywny wysiłek badawczy zaowocował monografiami bibliotek: Macieja z Miechowa i Piotra Tomickiego, które stały się podstawą uzyskania stopnia doktora (1960) i habilitacji (1961, zatwierdzenie ministerialne: 1962) na Wydziale Filozoficzno-Historycznym UJ.

Hajdukiewicz rozwinął badania nad reformacją, humanizmem i staropolską oświatą, wplatając w nie wątki śląskie. Badania nad reformacją i Śląskiem nie były później przez niego uprawiane. W rękopisie przetrwało tylko opracowanie pt. Dzieje krakowskiej gminy kalwińskiej, nigdy nie podane do druku'. We fragmentach przechowaty się maszynopisy rozpraw dotyczących oświaty i humanistycznej kultury Śląska: o szkolnictwie Wrocławia w XVI w. i jego związkach z polskimi humanistami oraz o wrocławskich studiach Jakuba Wujka ${ }^{7}$. $\mathrm{Z}$ zakresu swoich badań nad Erazmem z Rotterdamu opublikował tekst o intelektualnych, książkowych i przyjacielskich więzach łączących wielkiego Holendra z Polską ${ }^{8}$. Zamierzał poszerzyć te studia o dzieje nauki w epoce nowożytnej. Pobyt na stypendium w Bazylei w 1963 r. miał zaowocować anonsowanym w sprawozdaniach artykułem o metodologii badań naukowych w Europie XVII w., a zwłaszcza o zagadnieniach syntezy i encyklopedii nauk ${ }^{9}$, z czego jednak uczony zrezygnował. Od 1959 r. rozpoczął trwającą do końca życia współpracę z Redakcją Polskiego Stownika Biograficznego, która niezwykle

${ }^{6}$ AUJ, sygn. Sp. 168/39. Wiemy też, że planowany był artykuł pt. Akademia Rakowska.

${ }^{7}$ AUJ, sygn. Sp. 168/49 (mps, s. 6-25, bez końca), 91 (mps, ss. 5, bez końca). Odpryskiem tej tematyki jest krótki tekst Udziat Uniwersytetu Jagiellońskiego w odbudowie szkót wyższych Wroctawia 1945-1946, AUJ, sygn. Sp. 168/44 (mps, ss. 4).

${ }^{8}$ Pierwotnie planowany tekst był znacznie dłuższy niż wersja opublikowana. Por. Dwie karty z dziejów stosunków książkowych między Polska a Bazyleq w XVI w., AUJ, sygn. Sp. 168/47 (liczne wersje rękopiśmienne).

${ }^{9}$ AUJ, sygn. Sp. 168/9, 168/12. 
mocno naznaczyła jego twórczość. Przyrastający materiał do biografii krakowskich profesorów epoki renesansu dawał mu też okazję do czynienia wielu uzupełnień i korekt w pracach publikowanych przez innych, czego dowodzi ostatecznie zarzucony pomysł napisania polemiki Na marginesie artykutu o Mikotaju $z$ Wieliczki ${ }^{10}$.

Głównym zadaniem badawczym był jednak wówczas temat „Rola książki w tworzeniu kultury naukowej w Polsce okresu renesansu" (inne wersje tytułu: Rola książki w postępie myśli naukowej Odrodzenia, Czytelnictwo książki naukowej w Polsce w dobie Odrodzenia). Fragmentarycznie zachowany konspekt projektu obejmował następujące zagadnienia: 1) stan i problematyka badań nad historią czytelnictwa, 2) biblioteki jako ośrodki pracy naukowej w epoce odrodzenia, 3) książka jako źródło i narzędzie pracy badawczej ${ }^{11}$. W ramach jego realizacji miało dojść do opracowania trzech monografii wielkich księgozbiorów, poprzedzonych wstępem o rozwoju bibliotek i czytelnictwa książki naukowej w Polce w wieku XVI. Udało się opublikować dwie wybitne monografie bibliotek Macieja z Miechowa i Piotra Tomickiego. Nie została ukończona trzecia część, o bibliotece i roli książki w warsztacie naukowym Stanisława Grzepskiego, profesora filozofa, filologa, numizmatyka, matematyka i humanisty, jednej z najciekawszych osobowości akademickiego środowiska krakowskiego Złotego Wieku. W druku po latach ukazało się tylko syntetyczne podsumowanie, choć praca była już bardzo zaawansowana, w 1957 r. anonsowana w sprawozdaniach jako niemal gotowa i obliczana na 10 arkuszy wydawniczych. Planowany tytuł brzmiał „Warsztat naukowy Stanisława Grzepskiego (1525-1570). Monografia zbiorów na tle działalności naukowej”. Pozostały po niej obfite wypisy źródłowe, przepisany na maszynie szesnastowieczny inwentarz biblioteki, duże partie opisów druków zidentyfikowanych z egzemplarzami zachowanymi w zbiorach starych druków Biblioteki Jagiellońskiej, przerysy wielu opraw, opracowania wstępne biblioteki i biografii Grzepskiego.

Z tym projektem wiązał się także zamiar edycji najstarszej zachowanej księgi wypożyczeń biblioteki Kolegium Większego (BJ, rkps 242), z czego ostał się odpis pierwszych siedemnastu kart rękopisu ${ }^{12}$.

${ }^{10}$ AUJ, sygn. Sp. 168/91. Dotyczy artykułu M. Skulimowskiego, Mikotaj z Wieliczki, lekarz i uczony polskiego Renesansu (1489-1559), „Kwartalnik Historii Nauki i Techniki”, IV, 1959, 4, s. 621-631.

${ }^{11}$ W. Szulakiewicz, op. cit., s. 85. Zob. też AUJ, sygn. Sp. 168/12.

12 AUJ, sygn. Sp. 168/87. 
Drugi okres twórczości L. Hajdukiewicza orientacyjnie zamyka się w latach 1963-1978. Świeżo habilitowany, z opinią znakomitego badacza i sumiennego pracownika, znalazł się on w trudnej sytuacji, ponieważ nie miał szans na docenturę etatową w macierzystej katedrze. Oferowano mu stanowisko dyrektora w Bibliotece Uniwersyteckiej we Wrocławiu. Mając poparcie Bogdana Suchodolskiego, sondował możliwość zatrudnienia w Zakładzie Historii Nauki i Techniki PAN. W Uniwersytecie Jagiellońskim znaleziono jednak sposób na zatrzymanie go w Krakowie. W 1963 r. H. Barycz ustąpił na rzecz Hajdukiewicza ze stanowiska kierownika Archiwum UJ, które jego uczeń objął jako docent etatowy, prowadząc ciągle jako adiunkt zajęcia dydaktyczne dla studentów pedagogiki i historii w Katedrze Historii Nauki i Oświaty UJ ${ }^{13}$. W 1968 r. docentura etatowa została przeniesiona z Archiwum do katedry, lecz wniosek o stanowisko profesora nadzwyczajnego nie znalazł uznania w Ministerstwie Nauki, Szkolnictwa Wyższego i Techniki. Tytuł i stanowisko profesora nadzwyczajnego Hajdukiewicz uzyskał dopiero w roku 1973. Oprócz tego współpracował z PAN, będąc w latach 1973-1979 członkiem jej Komitetu Historii Nauki i Techniki. Był ponadto członkiem rad i komitetów redakcyjnych wielu czasopism i wydawnictw. W 1978 r. jako przedstawiciel Polski wszedł w skład International Commission for the History of Universities.

W okresie tym kontynuował wnikliwe badania nad bibliotekami staropolskimi. $Z$ tego czasu pochodzi znakomita rozprawa o Bibliotece Jagiellońskiej i o zagadnieniach erazmiańskich. Walor erudycyjnej syntezy miało jego opracowanie kultury renesansowej Krakowa. W 1974 r. na międzynarodowej warszawsko-krakowskiej sesji naukowej poświęconej 500-leciu drukarstwa w Polsce Hajdukiewicz wygłosił bardzo dobrze przyjęty referat pt. „Czytelnictwo w Polsce XVI-XVII w. Stan badań, problematyka, postulaty"14. Sam jednak oceniał, że powinien go mocniej podbudować materiałowo i - mimo nalegań Alodii Kaweckiej-Gryczowej - nie oddał tekstu do druku ${ }^{15}$. Nie

${ }^{13} \mathrm{~W}$ spuściźnie pozostały liczne wypisy i wersje wykładów z zakresu historii szkolnictwa, kultury, archiwistyki, bibliografii, drukarstwa, a także materiały seminaryjne, recenzje itd.

14 Zob. „Kwartalnik Historii Nauki i Techniki”, XIX, 1974, 4, s. 780-781 (sprawozdanie K. Mrozowskiej).

${ }^{15}$ Korespondencja w tej sprawie: AUJ, sygn. Sp. 168/10, 168/13. Zachowały się fragmenty rękopiśmienne tekstu pisane ołówkiem (AUJ, sygn. Sp. 168/48). Zob. publikację Dawna książka i kultura. Materiaty międzynarodowej sesji naukowej 
doszedł też do skutku projekt opracowania dziejów kultury Małopolski w epoce wczesnonowożytnej. W 1973 r. Hajdukiewicz został zaproszony do grona autorów trzytomowego dzieła Dzieje Matopolski do rozbiorów, które zamierzał opracować Instytut Historii UJ. Wraz z Heleną Madurowicz-Urbańską miał redagować planowany na 20 arkuszy rozdział „Małopolska w XVI i w pierwszej połowie XVII wieku"16. Z 1974 r. pochodzi obszerny i ambitny konspekt tego rozdziału, poświęconego nauce, oświacie, kulturze i piśmiennictwu regionu ${ }^{17}$.

Wielkim wyzwaniem było zaangażowanie się w zbiorowe przedsięwzięcie Historia nauki polskiej w Zakładzie Historii Nauki i Techniki PAN. Hajdukiewiczowi przypadło, zgodnie z profilem jego studiów, zadanie przygotowania tomów dokumentacyjnych, których pierwotnie planowano trzy: biograficzny, bibliograficzny i kartograficzno-tabelaryczny. Ukazały się pierwsze dwa ${ }^{18}$. Hajdukiewicz kierował zbiorowymi pracami nad tomem szóstym, w którym znalazło się ponad 1300 biogramów pracowników, miłośników i mecenasów nauki i kultury. Było to zadanie przekraczające możliwości merytoryczne i czasowe szczupłego zespołu. Ponadto, sposób przygotowywania tomu VI przez redaktora wywołał konflikt z gronem współpracowników, zarzucających mu niedocenianie ich wkładu pracy i nieszanowanie praw autorskich $^{19}$. Na domiar złego tom spotkał się z nieuniknionymi - i w wielu wypadkach słusznymi - negatywnymi uwagami recenzentów ${ }^{20}$.

z okazji pięćsetlecia sztuki drukarskiej w Polsce, red. S. Grzeszczuk, A. Kawecka-Gryczowa, Wrocław 1975, s. 331-348 („Kronika sesji”).

16 AUJ, sygn. Sp. 168/3, 168/4.

17 AUJ, sygn. Sp. 168/49

${ }^{18}$ Nie ukazał się tom trzeci. W 1973 r. Hajdukiewicz informował B. Suchodolskiego, że największą trudnością było zebranie zespołu autorskiego i że w 1967 r. przeprowadzono zbieranie dokumentacji do pięciu map przekrojowych (szkół i środowisk życia naukowego w X-XV w., uczelni wyższych, gimnazjów akademickich i inicjatyw uruchomienia zakładów naukowych w XV-XVIII w., szkół zakonnych - głównie kolegiów jezuickich i pijarskich, szkół różnowierczych i protestanckich ośrodków naukowych, drukarń i naukowych ośrodków wydawniczych). Miały trwać prace nad materiałami do tablic synchronicznych ukazujących rozwój nauki polskiej i światowej w XIII-XVIII w., zob. AUJ, sygn. Sp. $168 / 13$.

19 Dodajmy, że kwestię sposobu podpisywania i honorowania praw autorów biogramów i Hajdukiewicza rozstrzygnął ostatecznie B. Suchodolski. Zob. korespondencję w tej sprawie: AUJ, sygn. Sp. 168/3.

20 O tomie biograficznym Historii nauki polskiej, „Kwartalnik Historii Nauki i Techniki”, XXI, 1976, nr 1, s. 93-105 (rec. J. Róziewicz, Z. Wójcik), s. 106-110 
Hajdukiewicz odebrał je jako niesprawiedliwe. Dzieło, zamiast sukcesu i spodziewanego prestiżu, przyniosło poczucie niespełnienia i niedocenienia.

Badania nad kulturą staropolską autor starał się rozszerzyć na kontakty Polski z krajami zachodnioeuropejskimi. Przygotował obszerną rozprawę pt. „Stosunki kulturalne między Polską i Flandrią do końca XVII w. (Próba syntezy)". Jej główne tezy referował 10 marca 1970 r. na zebraniu Zespołu Historii Nauki Okresu Odrodzenia PAN. Niestety, pozostała ona $\mathrm{w}$ niedokończonych, licznych wersjach rękopiśmiennych, na maszynie autor przygotował tylko konspekt całości ${ }^{21}$. Jak tego dowodzą obfite wypisy źródłowe i bibliograficzne, poświęcał się też intensywnie opracowywaniu stosunków kulturalnych Polski z Francją ${ }^{22}$. Ocalał wreszcie niedokończony, rękopiśmienny zarys stosunków polsko-szwedzkich ${ }^{23}$, być może pomyślany jako wstęp do księgi jubileuszowej dla Uniwersytetu w Uppsali.

Intensywnie zajmował się Hajdukiewicz historią oświaty. Jego wyrosła w kręgu Barycza wizja ujmowania tej problematyki na szerokim tle rozwoju kultury epoki, z dbałością o precyzyjną faktografię, najnowszy stan badań i niepoddający się schematyzmom język znalazły się w opozycji do metodologii i sposobu wykonania nowej syntezy dziejów wychowania, której pierwszy tom został opublikowany w 1966 r. pod redakcją Łukasza Kurdybachy jako dzieło Pracowni Dziejów Oświaty PAN ${ }^{24}$. Wraz Henrykiem Baryczem i Mirosławą Chamcówną przygotował wtedy wnikliwą, lecz nieopublikowaną, recenzję do "Przeglądu Historyczno-Oświatowego"25. Hajdukiewicz już wcześniej dostrzegał brak dobrej syntezy średniowiecznego szkolnictwa w Polsce oraz słabe wykorzystanie dorobku mediewistyki polskiej przez historyków oświaty i wychowania. Przekonał się o tym, pracując nad monografią przeznaczoną dla Historii nauki w Polsce.

(rec. T. Nowak); Z. Brocki, Uwagi do tomu biograficznego i bibliograficznego Historii nauki polskiej, „Slavia Occidentalis”, XXXVI, 1979, s. 163-166.

${ }^{21}$ AUJ, sygn. Sp. 168/26 i 168/58. Zob. „Kwartalnik Historii Nauki i Techniki”, XV, 1970, 3, s. 661-662.

${ }^{22}$ AUJ, sygn. Sp. 168/58.

23 AUJ, sygn. Sp. 168/41, 42.

${ }^{24}$ Historia wychowania, t. 1, red. Ł. Kurdybacha, Warszawa 1965.

25 Zob. K. Bartnicka, Eukasz Kurdybacha - twórca Pracowni Dziejów Oświaty (1907-1972), [w:] Instytut Historii Nauki Polskiej Akademii Nauk w latach 1953-2003. Księga jubileuszowa z okazji pięćdziesięciolecia dziatalności, red. J. Schiller, L. Zasztowt, Warszawa 2004, Instytut Historii Nauki PAN, s. 139; tekst całej recenzji w Archiwum Nauk PAN i PAU w Krakowie, spuścizna prof. H. Barycza. 
Rozprawa (zaawansowana już w 1961 r.) okazała się zbyt obszerna, dlatego w 1965 r. planowano jej podział i druk we wspomnianej syntezie oraz w „Studiach i Materiałach z Dziejów Nauki Polskiej”26. Wydaje się, że nie odpowiadało to autorowi postrzegającemu pracę jako samodzielny podręcznik. W 1972 r. opracowanie było gotowe i obliczane na 5 arkuszy. Niestety, nigdy nie zostało oddane do druku ${ }^{27}$.

Niedokończenie i nieopublikowanie ważnych pozycji z zakresu dziejów kultury i oświaty polskiej utrwaliły obraz Hajdukiewicza jako badacza dziejów Uniwersytetu Jagiellońskiego. On sam konstatował ten fakt, pisząc, że stał się nim niejako ex officio jako kierownik archiwum uczelni.

$\mathrm{Na}$ podstawie swego wykładu habilitacyjnego stworzył w 1963 r. nowatorskie opracowanie o koloniach akademickich, które nadal stanowi podstawową pozycję dotyczącą tego tematu (obok monografii Wojciecha Grzeleckiego oraz dzieła Barycza o szkołach Nowodworskich) ${ }^{28}$. Zamierzał tę problematykę poszerzyć o okres Szkoły Głównej Koronnej. Wygłosił na ten temat referat, ale nie złożył go ostatecznie do druku ${ }^{29}$. Do dziś nie dysponujemy całościowym zarysem losów kolonii akademickich w czasach reform KEN. W 1965 r. uwzględniany był udział Hajdukiewicza w planowanej przez Ludową Spółdzielnię Wydawniczą publikacji „Chłopi w dziejach Uniwersytetu Jagiellońskiego” (miał opracować rozdział pt. „Młodzież chłopska na Uniwersytecie Jagiellońskim do końca XVIII w.”). Nie wiadomo, na ile był to projekt narzucony autorowi, w każdym razie nie ma śladów, aby podjął studia $\mathrm{w}$ tym kierunku ${ }^{30}$. Takich zewnętrznych propozycji było zresztą wiele. $Z$ zaangażowania w pracę przy jubileuszu 500 -lecia urodzin Mikołaja Kopernika wyrósł zarys tradycji kopernikańskich na Uniwersytecie Krakowskim. Krótki, popularnonaukowy szkic dziejów

${ }^{26}$ AUJ, sygn. Sp. 168/3, 168/6.

27 AUJ, sygn. Sp. 168/43 (fragment mpsu), 44 (mps, rozdz. II-IV, VI, s. 11-62, 71-152).

28 Por. W. Grzelecki, Szkoty-kolonie Uniwersytetu Krakowskiego 1588-1773. Problematyka ksztatcenia i wychowania, Wrocław 1986, Ossolineum, Monografie z Dziejów Oświaty, t. 31; H. Barycz, Historia Szkót Nowodworskich od zatożenia do reformy H. Kottątaja, Kraków 1939.

29 W kręgu wielkiej reformy. Sesja naukowa w Uniwersytecie Jagiellonskim w dwusetna rocznice powstania Komisji Edukacji Narodowej 24-26 października 1973, red. K. Mrozowska, R. Dutkowa, Warszawa 1977, PWN, s. 177 (nazwisko autora i temat Kolonie akademickie $w$ dobie Komisji Edukacji Narodowej z adnotacją: „Tekst referatu nie został dostarczony”).

30 AUJ, sygn. Sp. 168/9. 
uczelni napisał do książki przygotowanej wespół z Mieczysławem Karasiem i pomyślanej jako kompendium dla odbiorcy zagranicznego. Nie udało się wszakże dokończyć szacowanego na 3 arkusze studium „U początków historiografii uniwersyteckiej (Z dziejów kształtowania się świadomości historycznej w Uniwersytecie Krakowskim)”. 9 maja 1967 r. referował tę rozprawę na posiedzeniu Zespołu Odrodzenia PAN ${ }^{31}$ (zamierzał zbadać okres od XV do XVIII w., w rękopisie naszkicował zagadnienie do połowy XVII w., a na maszynie przygotował tylko schemat pracy świadczący o erudycji i metodologicznej pre(cyzji) ${ }^{32}$. Za ciekawy przyczynek do dziejów uczelni, a zarazem świadectwo horyzontów badawczych i powrotu do prac z lat młodzieńczych uznać trzeba opracowanie pt. „Władysław Orkan a Uniwersytet Jagielloński”. Powstało ono w 1975 r. na sesję naukową zorganizowaną w 100. rocznicę urodzin pisarza. Z gęstego rękopisu (29 stron) wyrósł jednak tylko jedenastostronicowy maszynopis pomyślany jako mowa inauguracyjna ${ }^{33}$. Największym wkładem do dziejów Uniwersytetu okazały się biogramy dla PSB, któremu na jubileusz wydania tomu dwudziestego poświęcił piękną laudację. Jak sam podkreślał: „Uprawiam ten gatunek mimo nie najwyższych notowań na giełdzie naukowej bez kompleksów i oporów, z całą świadomością ich znaczenia i przydatności dla badań nad historią kultury naukowej w Polsce. [- ] Pracochłonność tego typu 'mikrografii' nie mogła oczywiście pozostać bez wpływu na 'liczące się' w dorobku naukowym większe formy piśmiennicze" 34 . Do końca życia sam lub we współautorstwie napisał aż 103 biogramy, co stawia go w gronie najbardziej płodnych współpracowników tego zasłużonego wydawnictwa.

Zapleczem materiałowym dla tej mrówczej twórczości był prowadzony przez niego w Archiwum UJ projekt „Corpus academicum Cracoviense” - obejmujący biografie bakałarzy, magistrów, doktorów i profesorów UJ. Część staropolską opracowywał osobiście, a lata 1780-1918 przygotowywali pracownicy archiwum. Trzeba bowiem podkreślić, że Hajdukiewicz przejął po Baryczu i rozwinął ideę archiwum uniwersyteckiego jako placówki naukowo-badawczej. Kierowanie tą instytucją okazało się wszakże bardzo czasochłonne, zwłaszcza akcja scalania zbiorów i przeprowadzka do nowej siedziby w Kolegium

31 Zob. „Kwartalnik Historii Nauki i Techniki”, XII, 1967, 4, s. 866-867.

32 AUJ, sygn. Sp. 168/58.

33 AUJ, sygn. Sp. 168/42.

${ }^{34}$ AUJ, sygn. Sp. 168/83. 
Kołłątaja (1965-1974), później zaś prace remontowe i inwentaryzowanie rozrastającego się zasobu. Miarą problemów był fakt, że zgłaszane w 1971 r. do planu wydawniczego UJ Inwentarze akt Wydziałów i Studiów UJ w latach 1849-1939 (1954) ukazały się dopiero po śmierci Hajdukiewicza. Ze szkodą dla twórczości naukowej angażowała go także, jak sam to określał, „obsługa informacyjno-dokumentacyjna władz uczelni i innych instytucji”, zwłaszcza w zakresie aktualnych rocznicowych i urzędowych potrzeb rektoratu. Intensywna współpraca z rektorem Mieczysławem Karasiem (zm. 1977) odbiła się w opinii sporej części środowiska akademickiego negatywnym echem; Karaś, jako naukowiec zasłużony w badaniach językoznawczych, zrażał jednak wiele osób politycznym i ideologicznym zaangażowaniem, najpierw jako wieloletni I sekretarz Podstawowej Organizacji Partyjnej PZPR na UJ, następnie członek Komitetu Miejskiego i Wojewódzkiego w Krakowie, wreszcie zastępca członka Komitetu Centralnego. Hajdukiewicz spełniał rozliczne zlecenia jako autor (i ghost writer) przemówień rektora, a także redaktor, kwerendzista, konsultant, recenzent, autor scenariuszy wystaw i opracowań okolicznościowych. Przepracowanie i przemęczenie wpłynęło fatalnie na stan zdrowia. W 1978 r. przeżył rozległy wylew i udar mózgu, co pozostawiło po sobie trwały niedowład lewej części ciała i złamało jego siły fizyczne i umysłowe.

W ostatnim okresie twórczości (1979-1995), na koniec lekko rozświetlonym przyznaniem profesury zwyczajnej i godności członka-korespondenta PAU w 1993 r., słabło tętno pracy autorskiej i badawczej. Czas ten można traktować jako lata zmagania się wiedzy i chęci z własnymi (fizycznymi i wynikającymi ze specyficznego charakteru i posiadanej osobowości) ograniczeniami. Hajdukiewicz próbował podjąć zarzucone wcześniej studia czy skończyć (niestety, bez powodzenia) długofalowe przedsięwzięcia. Większość powstałych wówczas tekstów stanowi owoc wystąpień konferencyjnych oraz zapotrzebowań okazjonalnych i jubileuszowych; kilka nawiązywało do wcześniejszych badań nad kulturą i oświatą renesansu. Zestaw pokonferencyjnych artykułów o koloniach akademickich, peregrynacjach naukowych i młodzieży studenckiej miał dopełnić prekursorski artykuł pt. „Ad aulas nobilium. Z dziejów nauczania prywatnego w Akademii Krakowskiej”, ale nie udało się przeprowadzić nawet kwerend niezbędnych do jego napisania. Efektem stypendium w Wolfenbüttel w 1981 r. miała być rozprawa „Hermann Conring und Polen”, przeznaczona do księgi przygotowywanej przez Herzog August Bibliothek w Wolfenbüttel na trzechsetną rocznicę śmierci Conringa. Hajdukiewicz 
zbierał materiały do tego studium, ale ostatecznie go nie napisał ${ }^{35}$. Nie wywiązał się z zaproszenia do stworzenia tekstu „Bolonia i Polska. Studium powiązań kulturalnych w XV i XVI wieku” do księgi pamiątkowej ofiarowanej Uniwersytetowi Bolońskiemu przez historyków krakowskich i ograniczył się do udziału w komitecie redakcyjnym $^{36}$. Niezrealizowana pozostała też umowa z 1986 r. na napisanie tekstu „Historia Uniwersytetu Jagiellońskiego (1850-1870)”37. Inaczej stało się z referatem „Die erste österreichische Professoren an der Jagellonischen Universität am Anfang des 19. Jahrhundert” wygłoszonym na międzynarodowej konferencji nt. „Universitäten und Professoren. Die Migrationen der Hochschullehrer in Mittel-, Ost- und Südosteuropa vom 18. bis zum 20. Jahrhundert" (Klosterneuburg, 21-23 czerwca 1988 r.). Przygotowana rozprawa nie wyszła drukiem, nie wydano bowiem tomu pokonferencyjnego ${ }^{38}$.

W latach 1984-1988 L. Hajdukiewicza powołano do międzynarodowego zespołu autorów opracowujących syntezę „History of the European Universities in Society”. Przydzielono mu w drugim tomie, obejmującym lata 1500-1800, rozdział pt. „Internal infrastructure and organisation (resources and their management)" ${ }^{39}$. Mimo chęci i wstępnych przygotowań, ostatecznie nie podjął tego prestiżowego, ale trudnego zadania ${ }^{40}$.

W Archiwum UJ, którym kierował do przejścia na emeryturę w 1994 r., lata te noszą piętno zastoju. Nie zrealizowano zespołowych projektów badawczych: „Rektorzy UJ (1364-1964). Zarys dziejów urzędu” 41 oraz „Tytuły, godności i wyróżnienia naukowe Uniwer-

35 AUJ, sygn. Sp. 168/39. Brak tekstu artykułu. Zob. Hermann Conring (1606-1681). Beiträge zu Leben und Werk [Symposion der Herzog August Bibliothek (Wolfenbüttel) vom 9. bis 12. Dezember 1981], hrsg. von M. Stolleis, Berlin 1983, Duncker und Humboldt, Historische Forschungen, Bd. 23.

36 AUJ, sygn. Sp. 168/4. Zob. Commentationes historicae. Almae Matri studiorum Bononiensi novem saecula feliciter celebranti ab Universitate Iagellonica Cracoviensi oblatae, Warszawa-Kraków 1988, UJ, Varia, t. 232.

37 AUJ, sygn. Sp. 168/84.

38 AUJ, sygn. Sp. 168/28 (mps, j. niemiecki, ss. 33). O konferencji zob. „Österreichische Osthefte", XXXI, 1989, 1, s. 149.

39 AUJ, sygn. Sp. 168/61.

${ }^{40}$ Ostatecznie synteza ukazała się jako A History of the Universities in Europe, ed. by W. Rüegg, Cambridge 1996, Cambridge University Press. Polskim współpracownikiem tomu został A. Gieysztor.

41 Ostatecznie opracowanie takie jako zestaw popularnonaukowych biogramów przygotował Z. Pietrzyk (Poczet rektorów Uniwersytetu Jagiellońskiego, Kraków 2000, Jagiellonia S.A.). 
sytetu Jagiellońskiego XVIII-XX w.”, a z projektu „Straty osobowe i materialne Uniwersytetu Jagiellońskiego w czasie okupacji hitlerowskiej” wykorzystano jedynie część materiału w księdze upamiętniającej profesorów krakowskich aresztowanych podczas Sonderaktion Krakau (6 listopada 1939 r.). Po projekcie „Corpus academicum Cracoviense” (planowano sześć tomów) pozostały materiały do biografii pracowników poszczególnych wydziałów w XIX-XX w. oraz opracowanie Haliny Zwolskiej pt. „Uczniowie szkoły Głównej Koronnej 1780-1795”, które w swoim czasie mogło stanowić znaczący postęp w badaniach nad szkolnictwem epoki Komisji Edukacji Narodowej, a i dziś, po uzupełnieniach i korektach, warte jest druku ${ }^{42}$. Nade wszystko ugrzęzła w nieskoordynowanej masie wypisów (do ponad 10000 graduatów z XVI-XVIII w.) realizacja części staropolskiej „Corpus academicum Cracoviense”. Było to bez wątpienia opus vitae L. Hajdukiewicza, projekt, któremu poświęcał się do ostatnich chwil życia i który, obok znakomitych prac naukowych, ostatecznie zapewnia mu trwałe miejsce $\mathrm{w}$ dziejach nie tylko polskiej historiografii, ale polskiej humanistyki ${ }^{43}$.

Jak słusznie podkreślał Andrzej K. Banach, L. Hajdukiewicz nie zdołał dopełnić swego twórczego dzieła. Rzetelność naukowa, krytycyzm oraz precyzja w szlifowaniu detalu źródłowego i stylu przechodziły z biegiem lat w nadmierny perfekcjonizm. Dochodziła do tego trudna osobowość, na której mogły się odbić niełatwe, naznaczone

42 O tym projekcie zob. H. Zaleska, Mtodzież Szkoty Gtównej Koronnej w latach 1780-1794. Próba rekonstrukcji metryki uniwersyteckiej, [w:] W kręgu wielkiej reformy, s. 155-160.

${ }^{43}$ Materiały L. Hajdukiewicza do staropolskiej części „Corpus academicum Cracoviense" zostały w 1995 r. odkupione od wdowy i uporządkowane przez pracowników Archiwum UJ, gdzie są przechowywane. Liczą 36 teczek ułożonych alfabetycznie wypisów źródłowych, 2 teczki wypisów niezidentyfikowanych i 1 teczkę materiałów roboczych. Historii tego projektu zostanie poświęcony osobny tekst. Jego współczesne kontynuacje prowadzone w Archiwum UJ: Corpus studiosorum Universitatis Iagellonicae 1850/51-1917/18. A-Ż, red. J. Michalewicz, K. Stopka, Kraków 1999-2015, Archiwum UJ, Towarzystwo Wydawnicze „Historia Iagellonica”, Księgarnia Akademicka, Z prac Archiwum Uniwersytetu Jagiellońskiego. Seria C: Corpus studiosorum Universitatis Iagellonicae in saeculis XV-XX, cz. 1-8; „Corpus academicum Cracoviense. Elektroniczna baza studentów i profesorów Uniwersytetu Krakowskiego w okresie staropolskim 1364-1780”, projekt pod kierunkiem prof. dr. hab. K. Ożoga, realizowany w latach 2013-2018 na Wydziale Historycznym UJ we współpracy z Katedrą Telekomunikacji Wydziału Informatyki, Elektroniki i Telekomunikacji AGH w Krakowie, finansowany ze środków Narodowego Programu Rozwoju Humanistyki (11H 120264 81). 
wojną dzieciństwo bez ojca, a także okoliczności startu życiowego i kariery naukowej, nieprzebiegającej, mimo wielkiego talentu, bez problemów. Archiwum uniwersyteckim kierował z poświęceniem i znawstwem dla jego bezcennych zbiorów. Ambitne plany rozmijały się jednak z możliwościami zespołu, a dość apodyktyczny styl zarządzania i owa - jak to stwierdziła jedna z opinii - „obowiązkowość posunięta do przesady” coraz bardziej pogłębiały nieporozumienia. Napięcia te zaowocowały w 1980 r., w okresie „Solidarności”, buntem części pracowników, którzy wnosili o zmianę kierownika. Był też Hajdukiewicz surowym recenzentem i trudnym promotorem. Mimo to w Archiwum UJ współukształtował grupę archiwistów i historyków zasłużonych dla badań nad dziejami Uniwersytetu Jagiellońskiego, spośród których należy wymienić A. K. Banacha, Urszulę Perkowską, Wandę Baczkowską, Mieczysława Barcika. Choroba w końcu lat siedemdziesiątych uderzyła $\mathrm{w}$ niego $\mathrm{w}$ samym rozkwicie sił twórczych i udaremniła kontynuację wielu prac. Te, które pozostawił, cechowała niezwykle staranna analiza źródłoznawcza, wnikliwość warsztatowa, rozległość zainteresowań, erudycyjność ujęcia i wystylizowana forma. Świetny dorobek Profesora zachowuje w pełni znaczenie w prowadzonych dziś badaniach nad polską kulturą wieków XVI-XVIII.

\section{Bibliografia prac naukowych Leszka Hajdukiewicza ${ }^{44}$}

1951

Dzieje krakowskiej szkoty katedralnej w w. XVI-XVIII, „Sprawozdania PAU”, LII, 1951, s. 375-380.

Krakowska szkota zamkowa 1510-1801, „Studia do Dziejów Wawelu”, I, 1955, s. 203-348.

Przeglad badań nad dziejami reformacji i kontrreformacji $w$ Polsce $w$ latach 1939-1952, „Reformacja w Polsce”, XII, 1953-1955, 45/50, s. 150-214. Sesja Kallimachowska, OiRwP, I, 1955, s. 251-258.

${ }^{4}$ W ramach poszczególnych lat zastosowano następujący układ publikacji: książki, artykuły, tomy pod redakcją zawierające artykuł autorski, biogramy w PSB, tomy pod redakcją, recenzje, sprawozdania i głosy w dyskusji. 
1956

Problem historii nauki w podręczniku „Historia Polski” (na marginesie dyskusji przeprowadzonej w Zespole Odrodzenia Komitetu Historii Nauki PAN, Kraków, dn. 18 II i 2 III 1956), „Nauka Polska”, IV, 1956, 2-3, s. 313-319. [Głos w dyskusji] Stosunki kulturalne Ślaska z catościa ziem polskich, [w:] Odrodzenie w Polsce. Materiaty sesji naukowej PAN 25-30 października 1953 roku, t. 2: Historia nauki, cz. 1, red. B. Suchodolski, Warszawa 1956, PIW, s. 200-207.

1957

Rozwój myśli pedagogicznej Sebastiana Petrycego, [w:] Sebastian Petrycy. Uczony doby Odrodzenia, red. H. Barycz, Wrocław-Warszawa 1957, Ossolineum, Monografie z Dziejów Nauki i Techniki, t. 3, s. 157-205.

1959

Z przesztości szkót pińczowskich (1586-1914), „Przegląd Historyczno-Oświatowy", II, 1959, 2, s. 95-149.

PSB, 8/2, 1959: Goliniusz Btażej Bazyli (ok. 1545-1625), profesor i rektor Akademii Krakowski, kanonik krakowski, poeta humanistyczny, s. 221-223; Golinski Grzegorz (1593-1631), profesor Akademii Krakowskiej, s. 225-226; Gotkowic Szymon (zm. 1667), profesor jezyka hebrajskiego w Akademii Krakowskiej, kanonik wiślicki, s. 254-255.

[Rec.] A. Kamiński, Prehistoria polskich związków mtodzieży, Warszawa 1959, „Kwartalnik Historyczny”, LXVI, 1959, 4, s. 1298-1299.

[Rec.] P. G. Thielen, Die Kultur am Hofe Herzogs Albrecht von Preussen (1525-1568), Göttingen 1953, „Studia i Materiały do Dziejów Wielkopolski i Pomorza", V, 1959, 1, s. 430-438.

[Spraw.] Zjazd bytych wychowanków gimnazjum pińczowskiego, „Przegląd Historyczno-Oświatowy”, II, 1959, 1, s. 144-145.

1960

Biblioteka Macieja z Miechowa, Wrocław 1960, Ossolineum, Monografie z Dziejów Nauki i Techniki, t. 16.

Im Bücherkreis des Erasmus von Rotterdam. Aus der Geschichte der bibliophilen Beziehungen zwischen Polen und Basel im 16. Jahrhundert, „Kwartalnik Historii Nauki i Techniki”, V, 1960, Sonderheft nr 2, s. 49-102.

Übersicht der Literatur betreffend die kulturellen Beziehungen Polens zu Basel, „Kwartalnik Historii Nauki i Techniki”, V, 1960, Sonderheft nr 2, s. 223-232. Przyczynki do życia i twórczości Macieja z Miechowa, [w:] Maciej z Miechowa 1457-1523. Historyk, geograf, lekarz, organizator nauki, red. H. Barycz, Wrocław 1960, Ossolineum, Monografie z Dziejów Nauki i Techniki, t. 15 , s. $255-304$. 
Zainteresowania naukowe Macieja z Miechowa w świetle jego ksieggozbioru, [w:] Maciej z Miechowa 1457-1523. Historyk, geograf, lekarz, organizator nauki, red. H. Barycz, Wrocław 1960, Ossolineum, Monografie z Dziejów Nauki i Techniki, t. 15, s. 205-254.

PSB, 8/3, 1960: Gossinger Zygmunt (ok. 1465-1504), humanista, docent Akademii Krakowskiej, kanonik wroctawski, s. 358; Górski Jakub (1585-1652), doktor obojga praw, profesor i rektor Akademii Krakowskiej, kanonik kapituty katedralnej, s. 440-441; Grabianowski Andrzej (zm. 1683), doktor obojga praw, profesor Akademii Krakowskiej, kanonik krakowski, s. 463; Gregerowic Zygmunt (zm. 1652), profesor i rektor Akademii Krakowskiej, doktor teologii, s. 565-566.

PSB, 9/1, 1960: [współautor ks. A. Usowicz] Grzegorz ze Stawiszyna koto Kalisza (1481-1540), profesor filozofii i teologii, rektor Akademii Krakowskiej, s. 89-90; Grzywna Jakub (zm. 1531), lekarz i profesor Akademii Krakowskiej, s. 128.

[Spraw.] [współautorka I. Stasiewicz] Posiedzenia Zespotów Historii Metodologii, Odrodzenia i Oświecenia, „Kwartalnik Historii Nauki i Techniki”, V, 1960, 3-4, s. 543-546.

1961

Księgozbiór i zainteresowania bibliofilskie Piotra Tomickiego na tle jego dziatalności kulturalnej, Wrocław 1961, Ossolineum, Monografie z Dziejów Nauki i Techniki, t. 18.

Pliniusz w Europie, [w:] Pliniusz, Historia naturalna, wybór, tt. i kom. I. i T. Zawadzcy, Wrocław-Kraków 1961, Ossolineum, BN II, 128, s. XLV-XLXXVIII.

PSB, 9/2, 1961: Hadus (Hadelius) Jan (ur. ok. 1485), wędrowny poeta i humanista niemiecki, s. 225; Halicjusz Szymon (1576-1625), profesor wymowy w Akademii Krakowskiej, s. 247; Henik Maurycy Pawet (zm. 1623), podróznik, dworzanin Marcina Kromera, Stanistawa Hozjusza, Mikotaja Wolskiego, poliglota, s. 390-391; Heydecke (Mirica) Jan (ok. 1443-1512), humanista, pisarz miejski, proboszcz kościota Mariackiego w Krakowie, s. 496-497.

Kronika Uniwersytetu Jagiellonskiego za rok akademicki 1956/1957, red. H. Barycz, do druku przyg. L. Hajdukiewicz, K. Mrozowska, Kraków 1961, UJ, Varia, t. 8.

[Spraw.] [współautorzy A. Gella, I. Stasiewicz] Posiedzenie naukowe Dziatu Historii Nauk Spotecznych, „Kwartalnik Historii Nauki i Techniki”, VI, 1961, 2, s. 350-355.

[Spraw.] [współautorzy R. Dutkowa, I. Stasiewicz] Posiedzenie naukowe Dziatu Historii Nauk Spotecznych Zaktadu Historii Nauki i Techniki, „Kwartalnik Historii Nauki i Techniki”, VI, 1961, 3, s. 530-534. 


\section{2}

Kronika Uniwersytetu Jagiellońskiego za rok akademicki 1957/1958, red. H. Barycz, do druku przyg. L. Hajdukiewicz, K. Mrozowska, Kraków 1962, UJ, Varia, t. 9.

[Spraw.] [współautorzy I. Stasiewicz, M. Frankowska, P. Czartoryski] Posiedzenia naukowe Dziatu Historii Nauk Spotecznych Zaktadu Historii Nauki i Techniki, „Kwartalnik Historii Nauki i Techniki”, VII, 1962, 3, s. 407-413.

1963

Podstawy ideowe i organizacyjne kolonii akademickich Uniwersytetu Krakowskiego (1588-1773). (Stan badań - problematyka - postulaty), „Przegląd Historyczno-Oświatowy”, VI, 1963, 2, s. 137-200.

PSB, 10/3, 1963: Jakub z Kleparza (ok. 1484-1553), rektor Akademii Krakowskiej, profesor teologii, kanonik kapituty katedralnej, s. 356-357; Jan z Bazylei (zm. 1505), doktor medycyny, lekarz kapitut: gnieźnieńskiej i poznańskiej, s. 442-443; Jan z Dobry (zm. 1447), lekarz, profesor medycyny i rektor Akademii Krakowskiej, s. 449-450; Jan z Latoszyna (zm. 1494), profesor i rektor Akademii Krakowskiej, doktor teologii i prawa kanonicznego, s. 460.

[Spraw.] Badania naukowe w Szwajcarii (16 czerwca do 18 grudnia 1962), „Kwartalnik Historii Nauki i Techniki”, VIII, 1963, 3, s. 471-473.

1964

PSB, 10/4, 1964: Jan z Tarczyna (zm. 1569), profesor Akademii Krakowskiej, kaznodzieja nadworny Zygmunta Augusta, s. 483-484.

1965

PSB, 11/2, 1965: Jerzy z Tyczyna (przed 1510-1591), poeta humanistyczny, sekretarz królewski, agent dyplomatyczny przy Kurii papieskiej, s. 188-190.

[Głos w dyskusji] Cztery wieki Uniwersytetu Jagiellońskiego 1364-1764, „Kwartalnik Historyczny”, LXXII, 1965, 4, s. 839-846.

1966

Biblioteka Jagiellonska w latach 1655-1775, [w:] J. Zathey, A. Lewicka-Kamińska, L. Hajdukiewicz, Historia Biblioteki Jagiellońskiej, t. 1: 1364-1775, red. I. Zarębski, Kraków 1966, UJ, Varia, t. 21, s. 275-426.

Szkolnictwo i wychowanie okresu staropolskiego w problematyce badań dwudziestolecia 1945-1964, „Przegląd Historyczno-Oświatowy”, IX, 1966, 1, s. 7-62.

1967

Biblioteka Stanistawa Grzebskiego, „Przegląd Geodezyjny”, XXXVIII, 1967, 5 (Geometria to jest miernicka nauka. Materiaty Sesji Naukowej zorganizowanej 
przez Uniwersytet Jagielloński, Zaktad Historii Nauki i Techniki PAN i Stowarzyszenie Geodetów Polskich), s. 16-23.

PSB, 13/2, 1967: Koler Wactaw z Jeleniej Góry z humanistycznym przydomkiem Anthraceus (zm. 1546), lekarz, humanista, jeden z pierwszych hebraistów krakowskich XVI w., s. 313-314.

H. Lipska, K. Tatarowicz, Bibliografia piśmiennictwa do dziejów Uniwersytetu Jagiellońskiego, red. tomu L. Hajdukiewicz, Kraków 1967, UJ, Varia, t. 28.

\section{8}

Czasy renesansowej świetności, [w:] Kraków stary i nowy. Dzieje kultury, red. J. Bieniarzówna, Kraków 1968, PWN, s. 89-184.

PSB, 13/4, 1968: Konicz Stanistaw z Brzezin (zm. 1492), profesor teologii i rektor Akademii Krakowskiej, s. 507-508.

PSB, 14/1, 1968: [współautor J. Dobrzycki] Kopernik Mikotaj (1473-1543), astronom, ekonomista, lekarz, humanista, kanonik warmiński, s. 3-16; Korona Marek (ok. 1590-1651), franciszkanin, teolog, kaznodzieja i pisarz polemiczny, s. 96-97.

Studia i Materiaty z Dziejów Nauki Polskiej, seria A: Historia nauk społecznych, z. 12 [Profesorowi Henrykowi Baryczowi w czterdziestolecie pracy naukowej przyjaciele, współpracownicy, uczniowie], red. L. Hajdukiewicz, Warszawa 1968: Bibliografia prac prof. dra Henryka Barycza 1923-1966, s. 11-44; Nieznany inwentarz instrumentarium i biblioteki Jana Brożka z roku 1657, s. 303-325.

Wyższe uczelnie Krakowa. Informator, red. nacz. L. Hajdukiewicz, Kraków 1968, Nakł. Krakowskich Szkoł Wyzszych.

[Anonimowo] Uniwersytet Jagielloński, [w:] Wyższe uczelnie Krakowa. Informator, red. nacz. L. Hajdukiewicz, Kraków 1968, Nakł. Krakowskich Szkół Wyzszych, s. 9-136.

Kronika Uniwersytetu Jagiellońskiego za rok akademicki 1965/1966, do druku przyg. T. Bujnicki, K. Mrozowska, W. Serczyk, red. tomu L. Hajdukiewicz, Kraków 1968, UJ, Varia, t. 39.

1969

PSB, 14/3, 1969: Kostowski (mylnie Kostkowski) Jerzy Grzegorz (zm. 1718), profesor astronomii i geometrii praktycznej $w$ Akademii Krakowskiej, wydawca kalendarzy, sekretarz królewski, s. 359-360.

[Rec.] H. Barycz, W blaskach epoki Odrodzenia, Warszawa 1968, „Kwartalnik Historii Nauki i Techniki”, XIV, 1969, 2, s. 358-365.

Jan Ponętowski - opat hradyski, bibliofil i mitośnik sztuki (Materiaty do życiorysu), „Roczniki Biblioteczne”, XIV, 1970, 3/4, s. 485-529. 
PSB, 15, 1970: Kraina (Crayno, Crainius, doctor Craina) Wojciech (ok. 1485-1559), docent Uniwersytetu Krakowskiego, doktor medycyny, rajca krakowski, s. 89-90; Kraśnicki Mateusz (zm. 1655), profesor teologii, rektor Akademii Krakowskiej, s. 232-233; Krupka Klemens z Wieliczki (ok. 1546-1604), bakatarz teologii, profesor Akademii Krakowskiej, prepozyt kościota Św. Mikotaja, s. 411; Krupka Sebastian (zm. 1625), profesor prawa i rektor Akademii Krakowskiej, kanonik katedralny i proboszcz wielicki, s. 415-416; Krypa Wojciech z Szamotut (zm. 1507), astronom, profesor Uniwersytetu Krakowskiego, lekarz nadworny królowej Elżbiety, s. 472-473; Krzykawski Krzysztof (zm. 1705), matematyk $i$ astronom, profesor teologii w Akademii Krakowskiej, s. 554-555.

Kronika Uniwersytetu Jagiellońskiego za rok akademicki 1966/1967, do druku przyg. L. Hajdukiewicz, Kraków 1970, UJ, Varia, t. 51.

[Rec.] Z. Ruta, Szkoty tarnowskie w XV-XVIII w., „Studia Historyczne”, XIII, 1970, 1, s. 164-168.

\section{1}

[Anonimowo] Biblioteki dworskie, [w:] Encyklopedia wiedzy o ksidżce, kom. red. A. Birkenmajer, B. Kocowski, J. Trzynadlowski, Wrocław-Warszawa-Kraków 1971, Ossolineum, kol. 210-215.

Erazm z Rotterdamu w opinii polskiej XVI-XVII w., [w:] Erasmiana Cracoviensia. W 500-lecie urodzin Erazma z Rotterdamu (1469-1536), „Zeszyty Naukowe UJ", 250, Prace Historyczne, z. 33, 1971, s. 55-85.

Herbert Czaja. Kim byt w Krakowie, „Życie Literackie”, XXI, 1971, 1, s. 6-7. PSB, 16, 1971: Kubalewicz Kazimierz (zm. 1723), profesor astronomii i teologii Akademii Krakowskiej, autor kalendarzy, s. 6; Kucharski Andrzej (ok. 1608-1679), doktor obojga praw i teologii, profesor, rektor i podkanclerzy Akademii Krakowskiej, kanonik krakowski, s. 45-46; Latos (Latosz, mylnie Latoszyński) Jan (ok. 1539-przed 1608), astronom i astrolog, profesor medycyny Akademii Krakowskiej, s. 569-572.

Kronika Uniwersytetu Jagiellońskiego za rok akademicki 1967/1968, do druku przyg. L. Hajdukiewicz, Kraków 1971, UJ, Varia, t. 59.

Kronika Uniwersytetu Jagiellońskiego za lata akademickie 1945/1946-1955/1956, red. kroniki L. Hajdukiewicz, oprac. J. Zieliński, M. Stępień, Kraków 1971, UJ, Varia, t. 64.

1972

PSB, 17, 1972: Leopolita (Kasprowicz, Nicz, Nicius) Jan "mtodszy”, profesor teologii Akademii Krakowskiej, kaznodzieja, wydawca i korektor pierwszego katolickiego przektadu Biblii (tzw. Biblii Leopolity lub Szarffenbergowskiej) na jezyk polski, s. 74-76; Lilia Piotr (ok. 1546-1605), teolog, mówca, kanonik poznański i prepozyt średzki, s. 332-334. 
1973

[Współautor J. Dobrzycki] Mikotaj Kopernik 1473-1543, [w:] Kopernik na Warmii. Życie i dziatalność publiczna, dziatalność naukowa, środowisko, kalendarium, red. J. Jasiński, B. Koziełło-Poklewski, J. Sikorski, Olsztyn 1973, Wydział Kultury Prezydium Wojewodzkiej Rady Narodowej, s. $19-44$.

PSB, 18, 1973: Lubrański Jan h. Godziemba (1456-1520), humanista, mecenas, dyplomata, biskup poznański, s. 81-84; Lubrański Tomasz h. Godziemba (zm. 1537), kasztelan brzeski, s. 85-86; Lukini (Luchini) Jan Antoni (1675-1750), prawnik, profesor i rektor Akademii Krakowskiej, s. 116; Eańcucki Wojciech (ok. 1610-1686), prawnik, profesor i rektor Akademii Krakowskiej, s. 206-207; Eacki Maciej h. Lis (ok. 1505-1557), prawnik, profesor i rektor Akademii Krakowskiej, scholastyk kujawski, archidiakon gnieźnieński, s. 307-308; Eyszkowic Wincenty (zm. 1641), doktor medycyny, lekarz krakowski, s. 612-613.

1974

Historia nauki polskiej, red. B. Suchodolski, t. 6: Dokumentacja bio-bibliograficzna. Indeks biograficzny tomu 1 i 2, oprac. L. Hajdukiewicz, Wrocław 1974, Ossolineum.

Wstęp, [w:] Historia nauki polskiej, red. B. Suchodolski, t. 6: Dokumentacja bio-bibliograficzna. Indeks biograficzny tomu 1 i 2, oprac. L. Hajdukiewicz, Wrocław 1974, Ossolineum, s. V-XII.

Wstęp, [w:] Katalog wystawy. 300 lat Drukarni Uniwersytetu Jagiellońskiego 1674-1974, Kraków 4 V-29 VI 1974, oprac. zespół w składzie W. Baczkowska, A. Gercz, W. Ptak-Korbel, E. Zwinogrodzka, pod kier. J. Pirożyńskiego, [Kraków] 1974, s. 3-15.

PSB, 19, 1974: [współautor J. Wiśniewski] Maciej z Krajny h. Topór, zwany Doktorem, Krajnq (Crayna), Lisem, pisat się też z Buzun (zm. po 1546), lekarz i bibliofil, s. 21-22; Maciej z Miechowa zwany Miechowita (ok. 1457-1523), lekarz, astrolog, geograf, profesor i rektor Akademii Krakowskiej, s. 28-33; Makowski Szymon Stanistaw (ok. 1612-1683), teolog, filozof, profesor i rektor Akademii Krakowskiej, s. 244-246; Marcin z Urzędowa (zm. 1573), botanik, lekarz, profesor Akademii Krakowskiej, kanonik sandomierski, s. 575-577; Mareniusz (Marennius) Stanistaw (ok. 1532-1580), filolog, teolog, profesor Akademii Krakowskiej, s. 631-632.

Kronika Uniwersytetu Jagiellońskiego za lata akademickie 1968/1969-1969/1970, red. L. Hajdukiewicz, do druku przyg. A. K. Banach, Warszawa-Kraków 1974, UJ, Varia, t. 85.

Studia z dziejów Drukarni Uniwersytetu Jagiellońskiego 1783-1974, red. L. Hajdukiewicz, J. Hulewicz, Kraków 1974, UJ, Varia, t. 91. 


\section{5}

Henryk Barycz (Sylwetki nowych cztonków PAN), „Nauka Polska”, XXIII, 1975, 8 (122), s. 47-58.

[Współautor M. Karaś] Jagellonskij Universitet. Istoričeskie tradicii, nastojašcee, budušcee, per s pol. D. Horowicz, A. Awdiejew, Cracov 1975, UJ, Varia, t. 101.

[Współautor M. Karaś] L'Universite Jagellone. La tradition, le présent, l'avenir, trad. J. Kowalska, Cracovie 1975, UJ, Varia, t. 101.

[Współautor M. Karaś] The Jagellonian University. Traditions, the Present, the Future, transl. by C. Grece-Dąbrowska, A. Zygalska, Cracow 1975, UJ, Varia, t. 101.

[Współautor M. Karaś] Uniwersytet Jagielloński. Tradycje, wspótczesność, perspektywy, wyd. 1, Kraków 1975, UJ, Varia, t. 101.

PSB, 20, 1975: Markiewicz Jan (1603-1687), kanonik poznański, warmiński, krakowski, polemista antyjezuicki, s. 22-24; Mateusz z Kościana (zm. 1545), teolog, profesor Akademii Krakowskiej, s. 195-196; Mateusz z Szamotut (ok. 1491-1528), astronom i astrolog, doktor dekretów, profesor Uniwersytetu Krakowskiego i Akademii Lubrańskiego, s. 198-199; Michat z Lublina (zm. 1528), doktor dekretów, fundator kolegiaty Św. Anny, s. 624-625; Michat $z$ Wislicy (ok. 1499-1575), profesor astrologii i teologii Akademii Krakowskiej, kanonik katedralny krakowski, s. 628-629.

J. Dobrzyniecka, Drukarnie Uniwersytetu Jagiellońskiego 1674-1783, „Zeszyty Naukowe UJ", 405, Prace Historyczne, z. 53, 1975, red. L. Hajdukiewicz. Historia nauki polskiej, red. B. Suchodolski, t. 7: Dokumentacja bio-bibliograficzna. Bibliografia dotyczaca treści tomu 1 i 2, oprac. W. Bieńkowski, J. Paruch, red. L. Hajdukiewicz, Wrocław 1975, Ossolineum.

Universitas rediviva. W 30 rocznice pierwszej powojennej inauguracji Uniwersytetu Jagiellońskiego 19 III 1945 r., oprac. i przyg. do druku zespół pracowników Archiwum UJ: W. Baczkowska, A. Banach, M. Barcik, L. Hajdukiewicz, U. Perkowska, H. Zaleska przy współudziale J. Koźlińskiej, H. Kręt, W. Magdziarza, red. L. Hajdukiewicz, „Uniwersytet Jagielloński. Biuletyn Informacyjny Rektora”, III (XXIX), 1975, ss. 100.

\section{6}

PSB, 21, 1976: Mikotaj z Koprzywnicy, starszy (zm. 1516), proboszcz w Ksiażnicach, s. 114-115; Mikotaj z Koprzywnicy, mtodszy (zm. 1542), prawnik, profesor i rektor Akademii Krakowskiej, rajca krakowski, kanonik kapituty katedralnej, s. 115-116; Mikotaj z Tuliszkowa (zm. ok. 1534), lekarz $i$ astrolog, profesor Akademii Krakowskiej, kanonik gnieźnieński, s. 144-145; Mikotaj z Wieliczki (ok. 1490-1559), profesor medycyny i rektor Akademii Krakowskiej, kanonik puttuski, scholastyk kielecki, s. 147-149; Modlinski Grzegorz (zm. 1654), doktor teologii i praw, profesor i rektor Akademii 
Krakowskiej, s. 523-524; Montanus Jakub (ok. 1524-1580), doktor medycyny $i$ teologii, kanonik krakowski i archidiakon lubelski, s. 664-665.

O tomie biograficznym nauki polskiej i kilku osobliwościach krytyki naukowej (J. Róziewiczowi i Z. Wójcikowi w odpowiedzi), „Kwartalnik Historii Nauki i Techniki”, XXI, 1976, 3, s. 509-534.

\section{7}

[Współautor M. Karaś] Die Jagellonen Universität. Tradition, Gegenwart, Perspektiven, übers. von R. Kiełbasińska, P. Lenz, wyd. 1, Kraków 1977, UJ, Varia, t. 134.

[Współautor M. Karaś] Uniwersytet Jagielloński. Tradycje, wspótczesność, perspektywy, wyd. 2, Kraków 1977, UJ, Varia, t. 134.

Studia $z$ dziejów oświaty $i$ kultury umystowej $w$ Polsce XVIII-XX w. Ksiega ofiarowana Janowi Hulewiczowi, kom. red. R. Dutkowa, J. Dybiec, L. Hajdukiewicz, Wrocław 1977, Ossolineum.

Geneza i poczatki Polskiej Szkoty Nauk Politycznych w Krakowie, [w:] Studia $z$ dziejów oświaty i kultury umystowej $w$ Polsce XVIII-XX w. Ksiega ofiarowana Janowi Hulewiczowi, kom. red. R. Dutkowa, J. Dybiec, L. Hajdukiewicz, Wrocław 1977, Ossolineum, s. 127-160.

PSB, 22, 1977: Mościcki Jakub (zm. ok. 1693), drukarz, wydawca, rajca lwowski, s. 148-149; Mucharski Jan Wincenty (1624-1690), doktor medycyny, lekarz nadworny Jana Kazimierza, s. 241; Mucharski Piotr (1594-1666), lekarz, profesor medycyny Akademii Krakowskiej, s. 241-243; Musceniusz Jan (ok. 1532-1602), profesor astronomii i teologii, rektor i podkanclerzy Akademii Krakowskiej, archidiakon kurzelowski, kanonik krakowski, s. 282-284; [współautorka H. Kowalska] Myszkowski Piotr h. Jastrzębiec (ok. 1510-1591), podkanclerzy koronny, biskup ptocki, potem krakowski, s. 382-390; Naymanowic (Najmanowicz) Jakub (ok. 1584-1641), profesor prawa i rektor Akademii Krakowskiej, kanonik katedralny krakowski, s. 640-645; Naymanowic (Najmanowicz) Krzysztof (ok. 1590-1651), lekarz, profesor medycyny i rektor Akademii Krakowskiej, rajca i burmistrz krakowski, s. 645-649; Nerwicjusz Marcin (ok. 1537-1582), profesor teologii Akademii Krakowskiej, kaznodzieja nadworny Zygmunta Augusta, s. 677-678; Nidecki Patrycy Andrzej (1522-1587), humanista, filolog, wydawca, sekretarz królewski, biskup wendeński (inflancki), s. 713-717.

Kronika Uniwersytetu Jagiellońskiego za lata akademickie 1970/1971-1971/1972, red. kroniki L. Hajdukiewicz, red. tomu U. Perkowska, Warszawa-Kraków 1977, UJ, Varia, t. 132.

[Rec.] Polski Stownik Biograficzny tom XX, „Kwartalnik Historyczny”, LXXXIV, 1977, 1, s. 157-166. 
1978

[Współautor M. Karaś] The Jagiellonian University. Traditions, the present, the future, revised ed., transl. A. Zygalska, C. Grece-Dąbrowska, A. Łagan-Delden, Cracow 1978, UJ, Varia, t. 136.

Wtodzimierz Budka (14 I 1894-1 III 1977), „Studia Źródłoznawcze”, XXIII, 1978, s. 262-264.

Kopernik w oczach dawnej i wspótczesnej nauki (Referaty wygtoszone na międzynarodowej sesji naukowej zorganizowanej z okazji pięćsetnej rocznicy urodzin Mikotaja Kopernika przez Uniwersytet Jagielloński i Polska Akademię Nauk, Kraków 14-15 września 1973, red. tomu L. Hajdukiewicz, oprac. i przyg. do druku W. Magdziarz, Kraków 1978, UJ, Varia, t. 125.

Les traditions coperniciennes à l'Université de Cracovie, [w:] Kopernik w oczach dawnej i wspótczesnej nauki (Referaty wygtoszone na międzynarodowej sesji naukowej zorganizowanej z okazji pięćsetnej rocznicy urodzin Mikotaja Kopernika przez Uniwersytet Jagiellonski i Polska Akademię Nauk, Kraków 14-15 września 1973, red. tomu L. Hajdukiewicz, oprac. i przyg. do druku W. Magdziarz, Kraków 1978, UJ, Varia, t. 125, s. 33-47.

PSB, 23, 1978: Niewieski Franciszek Stanistaw (zm. 1743), astronom i astrolog, wydawca kalendarzy, docent Akademii Krakowskiej, s. 88; Nowopolczyk (Novicampianus, Nowopolski) Wojciech (ok. 1504-1559), humanista, teolog, profesor Akademii Krakowskiej, wychowawca królewicza Jana Zygmunta Zapolyi, s. 377-379; [współautor A.K. Banach] Oborski Tomasz h. Pierzchata vel Roch (ok. 1571-1645), kanonik katedralny i biskup sufragan krakowski, s. 452-454; Ochocki Gabriel starszy (ok. 1601-1673), lekarz, profesor medycyny i rektor Akademii Krakowskiej, rajca i burmistrz krakowski, s. 492-495; Ochocki Gabriel mtodszy (zm. 1682), lekarz, profesor medycyny w Akademii Krakowskiej, rajca krakowski, s. 495-496.

[Głos w dyskusji] Dyskusja nad stanem badań tajnej oświaty w Polsce w latach drugiej wojny światowej, „Przegląd Historyczno-Oświatowy”, XXI, 1978, 4, s. 476.

[Anonimowo] Opole i ziemia opolska w tradycjach Uniwersytetu Jagiellońskiego, [Kraków 1979], UJ.

Szkoty pińczowskie w latach 1586 i 1914, [w:] Pińczów i jego szkoty w dziejach, red. J. Wyrozumski, „Zeszyty Naukowe UJ”, 512, Prace Historyczne, z. 62, 1979, s. 95-161.

PSB, 24, 1979: Ośliński Marcin (ok. 1647-1720), profesor teologii i rektor Akademii Krakowskiej, s. 614-615.

Charisteria Cracoviensia Universitati Regiae Uppsaliensi quinta sacra saecularia celebranti ab Universitate Iagellonica Cracoviensi oblata, ed. L. Hajdukiewicz, „Zeszyty Naukowe UJ”, 508, Prace Historyczne, z. 61, 1979. 
1980

Travaux préparatifs à l'édition du „Corpus Academicum Cracoviense”, [w:] L'Histoire des universités. Problèmes et méthodes. I're session scientifique internationale, Cracovie 13-14 mai 1975, réd. M. Kulczykowski, „Zeszyty Naukowe UJ", 567, Prace Historyczne, z. 67, 1980, s. 75-89.

PSB, 25, 1980: [współautorka H. Kowalska] Padniewski Filip h. Nowina (zm. 1572), podkanclerzy koronny, biskup krakowski, s. 1-7; Papenkowic Jakub (ok. 1582-1649), profesor teologii i rektor Akademii Krakowskiej, s. 165-167; Papenkowic Wojciech (ok. 1613-1681), profesor teologii i rektor Akademii Krakowskiej, s. 167-168; Pawet z Zakliczewa (zm. 1511), profesor Akademii Krakowskiej, kanonik ptocki, s. 400-401; Penatius Stanistaw (zm. 1570), humanista, pedagog, rektor lwowskiej szkoty katedralnej, s. 581; Petrycy Jan Innocenty (1592-1641), lekarz, profesor medycyny i historiograf Akademii Krakowskiej, rajca krakowski, s. 701-703.

Kronika Uniwersytetu Jagiellońskiego za lata akademickie 1972/1973-1974/1975, red. kroniki L. Hajdukiewicz, red. tomu H. Kręt, K. Plucińska, Warszawa-Kraków 1980, UJ, Varia, t. 142.

1981

PSB, 26, 1981: Piotr z Poznania (ok. 1504-1579), lekarz królewski, profesor Uniw. Krak., filantrop, s. 417-419; Piotr z Proboszczowic (ok. 1509-1565), astrolog, dr teologii, profesor Uniw. Krak., s. 420-421; Piotrowicki Jakub (ok. 1591-1643), profesor Uniw. Krak., prowizor Szkót Nowodworskich, s. 445-446; Plucieński (Pluciński) Franciszek Hieronim (ok. 1663-1723), profesor Akad. Krak., kanonik kijowski, s. 746.

1982

PSB, 27/1, 1982: Podgórski (Podgurski) Samuel Jan (zm. 1712), profesor Akad. Krak., kanonik sandomierski, s. 89-90.

PSB, 27/2, 1982: Pograbka (Pograbius) Andrzej (zm. 1602), lekarz, kartograf, s. 220-221; Polaczek Pawet Jan Józef (ok. 1700-1781), profesor teologii Akad. Krak., s. 263-264; Politowicz Dionizy Jan (ok. 1609-1671), profesor prawa Uniw. Krak., s. 315-316.

1983

History of the Jagiellonian University. A Calendar, [w:] The Jagiellonian University. University Guide-Book, Cracow 1983, UJ, s. 5-27.

Les colonies académiques de l'Université de Cracovie aux XVIe-XVII siècles, [w:] L'Université et l'enseignement extrauniversitaire XVI ${ }^{e}-X I X^{e}$ siècles. II ${ }^{e m e}$ session scientifique internationale, Cracovie 11-12 mai 1979, réd. M. Kulczykowski, „Zeszyty Naukowe UJ”, 657, Prace Historyczne, z. 73, 1983, s. $13-25$. 
Karol Wojtyta w Uniwersytecie Jagiellońskim 1938-1954, wstęp i oprac. L. Hajdukiewicz, Kraków 1983, UJ.

PSB, 27/3, 1983: Popiotek Józef Grzegorz (1704-1758), profesor, rektor i podkanclerzy Uniw. Krak., s. 590-591.

1984

Catalogue de l'Exposition. Université Jagellonne pendant l'ocupation hitlerienne (1939-1945), [w:] Universities during World War II. Materials of the International Symposium held at the Jagellonian University on the 40 anniversary of „Sonderaktion Krakau”, Cracow, October 22-24, 1979, ed. by J. Buszko, I. Paczyńska, „Zeszyty Naukowe UJ”, 643, Prace Historyczne, z. 72, 1984, s. 565-607.

1985

PSB, 28/2, 1985: Praczlewic Piotr Jan (ok. 1647-1711), profesor teologii, rektor i podkanclerzy Uniw. Krak., s. 333-334.

PSB, 28/4, 1985: Przectawczyk (Przectawowicz) Jan (ok. 1573-1635), profesor Uniw. Krak., s. 687-688.

1986

Bildungswesen und Wissenschaft in der Epoche der Jagiellonen, [w:] Polen im Zeitalter der Jagiellonen 1386-1572. Ausstellung auf der Schallaburg 1986, 8. Mai-2. November, Wien 1986, Katalog des Niederösterreichischen Landesmuseums, Neue Folge, Nr. 171, s. 77-85.

PSB, 29, 1986: Pudtowski Stanistaw (1597-1645), matematyk, fizyk, astronom, profesor prawa, rektor i podkanclerzy Uniw. Krak., s. 344-347; Racki (Radzki) Jan (ok. 1610-1682), profesor i historiograf Uniw. Krak., kanonik katedralny krakowski, s. 604-605.

1988

Du Moyen Age aux Lumières, [w:] Universités de Pologne 1364-1982, red. K. Mrozowska, Warszawa-Kraków 1988, UJ, s. 7-25.

PSB, 31/2, 1988: Rheticus (Retyk) Georg Joachim (1514-1574), matematyk, astronom i lekarz, profesor uniwersytetów $w$ Wittenberdze i Lipsku, uczeń Mikotaja Kopernika i propagator doktryny heliocentrycznej, s. 255-259.

1989

Gregor von Sanok, Erzbischof von Lemberg (um 1407-1477), [w:] Lexikon des Mittelalters, Bd. 4, München 1989, Artemis, szp. 1678.

Réflections sur les pérégrinations academiques des Polonais au XVII siècle, [w:] Les pérégrinations academiques. IV $V^{e m e}$ session scientifique internationale, Cracovie 
19-21 mai 1983, réd. par M. Kulczykowski, „Zeszyty Naukowe UJ”, 870, Prace Historyczne, z. 88, 1989, s. 13-25.

PSB, 31/4, 1989: Roliński Franciszek (ok. 1597-1674), lekarz, profesor medycyny $i$ rektor Uniw. Krak., s. 558-559; Romer Adam (ok. 1566-1618), humanista, teolog, profesor Uniw. Krak., proboszcz kościota św. Mikotaja, s. 626-627.

PSB, 32/1, 1989: Rosczewicz (Roszczewicz) Adam (zm. 1666), prawnik, profesor, rektor i podkanclerzy Uniw. Krak., s. 39-41.

Wyrok na Uniwersytet Jagielloński. 6 listopada 1939, red. L. Hajdukiewicz, Kraków 1989, KAW.

1991

Autour de problématique de la jeunesse de l'Université Cracovienne du $X V^{e}$ jusqu'au XVIII siècles, [w:] Les étudiants - liens sociaux, culture, moeurs du Moyen Age jusqu'au XIXe siècle. Vime session scientifique internationale, Cracovie 28-30 mai 1987, réd. M. Kulczykowski, „Zeszyty Naukowe UJ”, 950, Prace Historyczne, z. 93, 1991, s. 29-42.

Humanismus (Polen), [w:] Lexikon des Mittelalters, Bd. 5, München 1991, Artemis, szp. 202-204.

Spoteczne aspekty mecenatu literackiego $w$ Matopolsce $w$ czasach Jana Kochanowskiego, [w:] Cracovia litterarum. Kultura umystowa i literacka Krakowa i Matopolski w dobie Renesansu. Ksiega zbiorowa Międzynarodowej Sesji Naukowej w czterechsetlecie zgonu Jana Kochanowskiego (w Krakowie, 10-13 października 1984 r.), red. T. Ulewicz, Wrocław-Kraków-Warszawa 1991, Ossolineum, s. 117-141.

PSB, 32/4, 1991: Różycki Stanistaw (ok. 1604-1652), prawnik, profesor i rektor Uniw. Krak., kanonik katedralny krakowski, s. 542-543.

1992

Das Archiv der Jagellonischen Universität in Krakau, [w:] Archivpraxis und historische Forschung. Mitteleuropäische Universitäts- und Hochschularchive. Geschichte, Bestände, Probleme und Forschungsmöglichkeiten, hrsg. von K. Mühlberger, Wien 1992, Schriftenreihe der Universitätsarchiv - Universität Wien, 6, s. 62-79.

Die Krakauer Universität zur Zeit der frühen Renaissance, [w:] The Jagiellonian University in the Evolution of European Culture, scientific ed. J. Wyrozumski, Cracow 1992, Secesja, s. 25-48.

PSB, 34/2, 1992: Sabinka (Barttomiej ze Stradomia, Sabinius, Sabinus, Regiopontanus) Barttomiej (ok. 1506-1556), profesor Uniwersytetu Krakowskiego, doktor medycyny, lekarz królewski, s. 244-246. 
1993

Oleśnicki, Zbigniew, Bischof von Krakau (1423), Kardinal, Kanzler und Diplomat (1389-1455), [w:] Lexikon des Mittelalters, Bd. 6, München 1993, Artemis, szp. 1394-1395.

PSB, 34/3, 1993: Sattszewicz Wawrzyniec Józef (ok. 1700-1762), profesor astrologii i teologii Akad. Krak., s. 401.

1994

Henryk Barycz (1901-1994), „Acta Universitatis Iagellonicae”, XI, 1994, 6, s. $14-16$.

PSB, 35, 1994: Schilling Jan zw. Solidus h. wtasnego (ok. 1483-1518), humanista, kanonik krakowski i prepozyt wroctawski, s. 480; Schneeberger (Schneberger) Anton (1530-1581), lekarz, przyrodnik, humanista, s. 568-571; Schoneus (Schoen, Schön) Andreas, pseud. Eumorphus (1552-1615), poeta nowotaciński, profesor teologii, podkanclerzy i rektor Uniwersytetu Krakowskiego, s. 597-600.

1995

PSB, 36/1, 1995: Schroeter (Schroter) Adam (ok. 1525-ok. 1572), poeta nowotaciński, ttumacz, s. 3-4.

PSB, 36/2, 1995: Selig (Zelig, Hermazelig, Hermozelig) Stanistaw (zm. 1512), doktor medycyny i dekretów, profesor Uniwersytetu Krakowskiego, humanista, s. 193-194.

1997

Wydziaty i zaktady Uniwersytetu Jagiellońskiego w latach 1849-1939 (1954), [w:] Inwentarz akt Wydziatów i studiów Uniwersytetu Jagiellońskiego 1850-1939 (1954), red. J. Michalewicz, Kraków 1997, Z prac Archiwum Uniwersytetu Jagiellońskiego, Seria A: Inwentarz Archiwum Uniwersytetu Jagiellońskiego, t. 7, s. 7-24.

[Współautor M. Barcik] Wydziat Teologiczny (1850-1954), [w:] Inwentarz akt Wydziatów i studiów Uniwersytetu Jagiellońskiego 1850-1939 (1954), red. J. Michalewicz, Kraków 1997, Z prac Archiwum Uniwersytetu Jagiellońskiego, Seria A: Inwentarz Archiwum Uniwersytetu Jagiellońskiego, t. 7, s. 25-66.

[Współautorka W. Baczkowska] Tymczasowa Komisja Szkolna (9 wrzesień-6 grudzień 1939), [w:] Inwentarz akt Wydziatów i studiów Uniwersytetu Jagiellońskiego 1850-1939 (1954), red. J. Michalewicz, Kraków 1997, $\mathrm{Z}$ prac Archiwum Uniwersytetu Jagiellońskiego, Seria A: Inwentarz Archiwum Uniwersytetu Jagiellońskiego, t. 7, s. 487-490. 


\section{4}

Pliniusz w Europie, [w:] Pliniusz, Historia naturalna, wybór, tł. i kom. I. i T. Zawadzcy, wyd. 2, Wrocław-Warszawa 2004, Ossolineum - De Agostini Polska, Arcydzieła Kultury Antycznej.

Dr Maciej Zdanek, adiunkt w Archiwum Uniwersytetu Jagiellońskiego. Prowadzi badania w zakresie historii średniowiecza ze szczególnym uwzględnieniem dziejów instytucji kościelnych. E-mail: maciej.zdanek@uj.edu.pl. 